\title{
Research on the Development of China's National Music Against the Background of Cultural Soft Power
}

\author{
Rong Xing \\ Kunming University \\ Kunming, China
}

\begin{abstract}
At present, with the increasingly stable international environment, the influence of traditional elements such as military and economic competitiveness on the growth of national strength is gradually declining while the importance of national soft power such as cultural strength is increasingly prominent in the assessment of national strength. National music is the most representative type of culture in the national culture. The export and international communication of music culture have a significant role in promoting the promotion of national strength, and it is also a powerful channel for the dissemination of national ideology and national image. Based on the purpose of construction of China's cultural soft power, this paper explores the dialectical relationship between the development of national music and the construction of national cultural soft power, and proposes the direction and strategy of the development of national music in the context of cultural soft power to make contribution to the national cultural construction and soft power development.
\end{abstract}

Keywords-cultural soft power; national music; innovation; cultural brand

\section{INTRODUCTION}

American scholar Joseph S. Nye first proposed the concept of "soft power" in the 1990s. He believed that national soft power is a non-intuitive national strength that is different from the elements of traditional national power such as military, economy, and politics, etc. as well as the potential influence with the core of national external attraction, among which ideology such as culture is the key to the external influence of national soft power [1]. National music can be used as a carrier of national image and ideology communication. At the same time, cultural soft power can promote the development of national music. Therefore, the development of national music under the guidance of cultural soft power construction strategy is a long-term strategic value.

\section{CURREnT Status OF China's Cultural SoFt POWER CONSTRUCTION}

\section{A. Unbalanced Issues Between Cultural Development and Social and Economic Development}

Up to 2016, China has developed into the world's second largest economy. Under the leadership of the new Party Central Committee with General Secretary Xi Jinping as the core, China's political and military strength has also developed rapidly and ranked among the tops in the world. However, in the same year, China's music products ranked only 87 in the global music market, and the proportions in music market of the world's top five countries: the United States, Japan, Britain, Germany, and France are closer to global GDP [2]. It can be seen that the development of China's music culture does not match China's social and economic development process, and the problem of lagging development is obvious, which not only goes against the development of China's national music, but also is adverse to the construction of the influence of China's music culture and cultural soft power.

\section{B. The Soft and Hard Resources of Cultural Construction Are Insufficient}

The external performance of cultural soft power is the attraction to other countries and ethnic groups. Its internal strength depends on basic resources such as market, works (and products) and talents. At present, the marketization conditions for the development of China's national music are relatively poor. For example, due to the influence of imperfect copyright environment and cultural market conditions, the marketization degree of China's music industry is low, and the marketization conditions of national music as a niche music type is severer. At the same time, the market operators are small in scale and the scale of creators and number of new entrants, limited by the market conditions, is low, which further limits the product resources and talent conditions for the development of national music market. Under this background, the development of national music presents a vicious circle, and has difficulties in truly obtaining favorable conditions in the international dissemination of national culture, which in turn limits the 
contribution of national music to the soft power of national culture.

\section{Shocks of Diversified Culture}

The interweaving and collision of diversified culture in modern society is very diverse. Under the background of globalization and information age, the exchange and collision of culture between countries is increasingly frequent. Cultural integration promotes the development of global integration, and the cultural separation and elimination in cultural collision will eventually lead to the reduced core cultural strength resources of the failure party in collision [3], which will eventually hinder the construction of cultural soft power. From the characteristics of cultural soft power, countries with higher cultural influence will attract people from other countries to pay attention to their own culture, economic and social systems, ideas and values, and mainstream ideology, etc. However, China's reform and opening up was influenced by the influx of multiculturalism, Chinese people's confidence in Chinese culture has declined, and they tend to pursue the values under the non-mainstream ideology, which not only has become a threat to China's cultural security, but also limits the development of cultural soft power and poses a threat to Ideological development.

\section{THE DiALECTICAL RELATIONSHIP BETWEEN THE DEVELOPMENT OF NATIONAL MUSIC AND THE CONSTRUCTION OF CUlTuRAL SOFT POWER}

\section{A. The Development of National Music Is an Inevitable Element of the Construction of National Cultural Soft Power}

Culture is the foundation of civilization and a direct manifestation of the intrinsic energy of a country and a nation. It realizes the positive influence on the people of other countries in the process of self-expression and external communication to make them voluntarily generate identity and yearning, and then transforms itself into national cultural soft power. The national cultural soft power in the modern international society mainly covers three major elements: modern art, traditional art, and folklore and life. The gap between China and international leading countries in the development of modern art (including film and television, animation and comics, and games) is relatively large; in the development of traditional art (including architecture, music, painting, sculpture, poetry, and dance), there is isolated development of ethnic art and modern Western similar art, and superficialization of the modernization and cultural integration development of national culture in China, leading to the relatively small international influence; in terms of folklore and life (including language and writing, religion, diet, and sports, etc.), China's output is relatively small, and the actual influence is slightly insufficient.

From this point of view, the modernization conditions for the development of China's cultural soft power are insufficient. However, the five thousand years cultural accumulation of China is the advantage that most leading countries in the world today don't possess. Marxist cultural view holds that the integration of cultural art and barbaric society forms the cornerstone of modern society [4], and the cultural and artistic system formed in the development of modern society always has historical traces, which is the inevitable result of historical development. Therefore, traditional and national art culture is an inevitable factor in constructing the cultural symbol of a country and nation and making it spread quickly. Among them, ethnic music, as a core component of national art, is naturally an inevitable element in the construction of national cultural soft power.

\section{B. The Growth of National Cultural Soft Power Is Conducive to Promoting the Inheritance and Internationalization of National Music}

The practical results of cultural soft power cover the important influence of the improvement of national culture confidence. When national music is developed as the basic element of cultural soft power, the national recognition and confidence of national music will be significantly increased, which is conducive to promoting the development of artistic audiences and the growth of the number of creators. The former is conducive to improving the inheritance of national music, while the latter is conducive to enhancing the socialization conditions for the development of national music and promoting its dissemination in the international arena. From the perspective of cultural soft power, soft power is first and foremost a fact, which is the admiration of the people from other countries for culture of this country. In most cases, the basis of this admiration comes from the development of the domestic economy, and whether this admiration will eventually appear is limited by the ability of the country to produce a large number of excellent cultural works.

The modern art works that the construction of Chinese cultural soft power can rely upon are not competitive internationally. For example, in the field of art of music, there is a clear gap between the influence of China and Europe, Japan, South Korea and other mainstream music products exporting countries [5], while the nation Music does not have similar competitors in the world. For example, the consumers' evaluation of music works with ethnic and religious styles are mostly the "impression", "novelty" and "mystery" in the international music market, which can't be surpassed by pure modern and postmodern music works [6]. Due to the unique charm of national music, the creation and innovation of national music works have been significantly improved in the process of showing national cultural soft power. Therefore, it can be said that the development of national cultural soft power will promote the inheritance and spread of national music.

\section{The DEVElopment DiRECTION OF NATIONAL Music WITH THE GOAL OF THE DEVELOPMENT OF NATIONAL Cultural SOFT POWER}

\section{A. Enhancing the Social Status of National Music Culture}

Under the current construction conditions of China's cultural soft power, the culture and art industry must first be upgraded to the same level as economic, political and social development. Secondly, we should pay attention to the basic 
advantages of national music in the construction of national music soft power, and further enhance the social status of national music.

First, we should optimize the external environment from the industrial level of cultural development, so that the development of the cultural industry can be seen in the top value of social development to promote the expansion of the structure of cultural market. Only by promoting the improvement of domestic industry can the basic premise of expanding cultural output and cultural soft power be realized. In practice, priority should be given to the improvement of the policy system for industrial development. We should achieve the integration of cultural industries and mainstream industries from the perspectives of industrial planning, taxation and fiscal stimulus, and financial support, and realize the scale expansion of traditional cultural industries through the cluster effect of industrial chains; Then, within the industry, commercial management, operation and service innovation can be used to promote the diversified development of the industry's production and profit models to form a more complete format, thereby enhancing the market space and upgrading conditions of the cultural industry.

Second, we should strengthen the stimulation and support for the marketization of national music from the policy level as soon as possible. The market audience for ethnic music is low, but the charm of national music remains undiminished. In the era of information explosion, traditional art seems to have a gap with the volume of popular culture. The essence of the problem lies not in the art form itself, but in the sudden changes in contemporary aesthetics and the impact of multi-culture. Therefore, the marginalization of national music is temporary. From the perspective of historical materialism, the true classic art culture rich in connotation will inevitably remain for a long time [7], but in terms of short-term development, the development environment of China's national music is poor compared with that of popular music. Therefore, it depends to some extent on the support of national policies.

\section{B. Optimizing the Resource Support for the Development of National Music}

The relationship between soft power and hard power is not isolated, but is interrelated and mutually restricted. In the development process of cultural soft power, the hard power of cultural development is the inevitable foundation. Therefore, the development of national music in the context of the development of cultural soft power must obtain effective resources support, and the core resources that are needed can be divided into the following three categories:

First is the support from policy resources. The policy resources are mainly embodied in the policy for the promotion of national music education and the support policy for sub-sector industry of national music culture. Through such policy resources support, the influence of the national music development policy can be optimized to attract more practitioners, and then provide conditions for the scale development of the national music industry at the source.

Second is the support from market resources. At the micro level, market resources cover the operating rights, brands, distribution channels, customers and their customer stickiness of operating companies in the market. From the macro level of the national music market, these resources have relatively large defects among all enterprises in the cultural industry. In terms of management rights and brands, domestic cultural enterprises are not highly loyal to national music brands, lacking representative works and literary talents; in terms of distribution channels, there is no channel difference between ethnic music and other types of music, but there are obvious disadvantages in the internal support of the channel; in terms of customer and customer stickiness, the audience of ethnic music is narrow, and the stickiness of core customers and marginal customers is at two extremes. In essence, the loyalty to the market segment of national music is not high within the cultural market, and it lacks content innovation, characteristic marketing and user development support. Therefore, cultural enterprises must assume the basic responsibility for the supply of market resources for the national music development.

Third is the support of human resources. Human resources are the basic elements that determine the quality of the content production and marketization operation of national music. The above analysis mentions that the innovation in the content of China's national music is insufficient and the market development is imperfect, which is directly related to the lack of artistic talents and market talents in China's national music market. In 2017, the output of China's national music talents accounted for $9.13 \%$ of the total talent output of music majors. The talents engaged in the operation of the national music market in the music market accounted for $0.017 \%$ of the similar talents in the market. The proportion of dissertations and journal articles related to research on the national music market in the music market research is about $31.9 \%$ [8]. It can be seen that the research field has a high degree of attention to the development of folk music, but the proportion of corresponding talents engaged in practical work is far below this level. Although this is related to the lower market conditions and support, it can also explain the corresponding talents have relatively low interests in the nation music industry.

\section{Strengthening the Promotion and Publicity of National Music Culture}

The promotion and publicity of national music is a necessary condition to solve the realization of the core elements of cultural soft power under the impact of multiculturalism. Through the promotion and publicity of national music culture, the recognition and acknowledgement of public to the national music can be enhanced, and at the same time the influence of national music in the international arena will be strengthened, so that the benign cycle development of national music and national cultural soft power can be achieved. In the domestic promotion and publicity, we can promote the scale of 
audience resources of the national music market, enhance the internal drive of the development of the sub-industry, and inject more sufficient funds into the national music market with the advantage of China's current domestic demand growth; in international promotion and publicity, with the symbolic function of characteristic national music, we can enhance the cognition of Chinese traditional culture of the international society, and at the same time, we can attract more foreign people to understand Chinese culture and consume Chinese cultural products to truly realize cultural output and build stronger cultural soft power. On this basis, we can inject more exogenous resources into the domestic national cultural industry.

\section{The National Music DeVelopment Practice STRATEGY WITH THE GOAL OF NATIONAL CULTURAL SOFT POWER CONSTRUCTION}

\section{A. Comprehensively Expanding the Channels for the Development of National Music Marketization}

At present, the development conditions of China's cultural market are becoming more and healthier. There is no obvious defect in the national music compared with other forms of music at the basic level. However, the endogenous motivation of the development of the existing national music market is insufficient, so it is necessary to develop a new type of channel especially for the national music market. First of all, we should implement a wider range of national music communication relying on the new media, and effectively support the national music marketing and promotion resources within the cultural industry. Secondly, it is suggested that folk music groups can cooperate with largescale cultural enterprises, and the group itself should create new excellent works. Large-scale cultural enterprises will inject effective capital into the production and dissemination of national music and expand the territory of the national music market. Finally, the policy should provide support within the industry and professional fields. The industry support can realize the dependence of the national music market on other advantageous industries and advantageous resources through social financing, cultural output mode, and integrated industrial chain guidance to promote large-scale development. The support in the professional field can provide sufficient talent and hardware resources for the development of national music market based on the construction of specialized venues for local ethnic music, talent development and support, and related research support related to cultural innovation and communication.

\section{B. Professional Colleges and Research Institutions Strengthen the Innovation and Creation of National Music}

In the spread of music culture in modern society, the biggest disadvantage of national music over popular music is the alienation of cultural complex. In the case of American country music, it belongs to American national music in a certain sense, but its content and form are highly related to modern American immigration culture. Therefore, the era of music works and the sense of audience affinity didn't miss obviously. However, Chinese national music originated from the Chinese agricultural society. In the rapid development of modern China, a large number of grassroots people have a greater isolation from the living habits of the farming society. A few producers who remain in the agricultural production field are also affected by the mechanization and information age and gradually alienate from the agricultural society [9], which is the root cause of the alienation of national music from the modern public aesthetic. The best way to solve this problem is to integrate modern elements in the creation of national music and adopt a more open vision and ideas to accept new culture when retaining the unique style of national music, which can effectively enhance the recognition of national music in the domestic audience and make it easier to attract the attention of foreign people, truly making national music works an effective resource for the development of cultural soft power.

\section{Local Governments Should Construct a Number of National Music Products with Distinctive Brand Effects}

From the perspective of short-term and medium-term development, it is difficult for the national music culture to really get out of the barrier of "niche culture". The author believes that the "niche culture" cannot be completely revived by the simultaneous development of macro-policies, which is not in line with the actual mass conditions of "niche culture" and the diverse characteristics of Chinese national music culture. The local government's image construction and product development around local characteristics of national music culture is more conducive to the rapid construction of national music brands with greater social influence and recognition. When the brand is formed, it can realize regional expansion and group infiltration through symbolic communication to achieve intensive use of resources for the development of the national music market. When the artistic brand and image of national music are established, the multi-regional characteristic brands can try further link to truly realize the geographical grid of the development of national music. On the one hand, we can build a more distinctive multi-ethnic national music culture image, and on the other hand we effectively guarantee the inheritance and development of national music.

\section{Enriching the Incentive Policies for Talent Development and Content Innovation in the National Music Field}

Talents are the fundamental constraints of the content creation of national music and the development of the industry. For the actual development needs, the state can provide more effective incentives for two types of professional talents. For creative and performing talents, the certification with middle and low thresholds for talent qualification and abilities can be provided, and for the related research talents, more favorable project funding support can be provided. They can make reward mechanism mainly for the creative and performing talents participating in college education and creative work of original works and drive the force of talents in the innovation and creation of national music content while expanding the scale of professional talents; for market talents, we can open more types of projects on national music market development, 
communication development, and brand development, and at the same time formulate the market-oriented transformation requirements of the corresponding projects to first improve the number of market management talents in the national music segment market, then achieve the targeted employment of talents with restrictive conditions and promote social and cultural enterprises to actively participate in the production and promotion of ethnic music products.

\section{E. Innovative Design of the Fusion Creation of Ethnic Music and International Communication Programs}

The ultimate goal of the development of cultural soft power is to realize the attraction of culture to foreign people, and to form the "vision, yearning, and worship" of foreign people on China's culture. The essence of cultural content innovation, cultural brand construction, cultural market optimization, and talent incentives, etc. mentioned above is the optimization of cultural content, and music culture, which has a certain form of "quick consumption", must inevitably undergo market testing to determine its influence, otherwise the new national music culture of so-called "ethnic music style + modern music elements" constructed with imaginary gestures may not be able to become an effective part of cultural soft power. Therefore, the main point of the fusion creation of national music with the goal of constructing cultural soft power lies in grasping the cultural attraction, rather than rigidly emphasizing the full preservation of the elements of national music. Referring to the status of music culture output and soft power of the United States, Britain, Japan, and South Korea, national music is not a decisive factor, but an effective factor in the construction of soft power. Those really occupy the forward position in the cultural output are usually "the popular music elements with strong cultural characteristics"[10]. For example, the export of Korean culture is usually based on the export of popular culture, and some of national culture. After establishing effective cultural attraction, they attract foreign people to understand and know their own culture. At present, there are two extremes in the national music culture that China exports to the outside world. One is the "high level" professional concert that over-emphasizes the nature of national music, of which the audience is extremely limited. The second is the Chinese style output of music works that over-emphasizes popular culture. The characteristics of such works are insufficient, and it is difficult to form an effective international attraction. Therefore, the author suggests that social and cultural enterprises should pay attention to the creation and orientation of the integration of national music and international popular music for the masses, retain some of the characteristics of national music to enhance the attraction of the works, attract the attention of foreign people, and at the same time attract them to deeply understand the national music with Chinese characteristics, thereby realizing the cycle of the development of national music and the construction of cultural soft power.

\section{CONCLUSION}

Excellent cultural products are essentially by-products of superior economic conditions. After the problem of food and clothing is solved, people began a higher level of pursuit. Therefore, the development of national music must first ensure the improvement of the basic market and the development of professional talents. On this basis, a large number of high-quality products will be produced, among which there will be excellent cultural products. Such cultural products are exported under the guidance of scientific international communication ideas, and finally transformed into effective components of national cultural soft power. This is a reasonable way for the development of Chinese national music under the background of cultural soft power development.

\section{REFERENCES}

[1] Joseph Nye. Rethinking "Soft Power" [J]. Social Sciences Abroad 2006 (4): 90-91.

[2] Fleming S D I. The Antiquarian Music Market in the Twenty-First Century: From the Perspective of a Collector [J]. Notes, 2016 72(4):678-689.

[3] Zhang Qinghua. The Spirit of Education in the Process of Chinization of Foreign Cultures in Modern Times and Its Changing Logic [J]. Social Sciences in Ningxia, 2017(5): 235-241.

[4] Tang Kailin. Adhering to the Scientific Attitude and Principle Position of Marxism in Treating Human Cultural Heritage Thinking from the Report of the 19th National Congress of the Communist Party of China [J]. Studies in Ethics, 2018(1):1-6.

[5] Liu Cong. Metaphysical Reconstruction in the vision of Aesthetic Modernity - From Speculative Art Theory to Marx Philosophy[J]. Seeking Truth, 2018,45(01):24-30.

[6] Perlovsky L. Music and Culture [M].Music, Passion, and Cognitive Function. 2017: 183-184.

[7] Dang Shengyuan. Research on Historical Materialism and Chinese Literary Thoughts [J]. Literary Heritage, 2017(3): 4-7.

[8] Liu Dai, Zhu Yongbei. Inheriting the predecessor and enlightening the Thought of the descendant - On the Traditional Music Culture and the Cultivation of "Human" in College Music Education [J]. Musical Creation, 2017(10): 178-179.

[9] Zhang Yanli. Reflections on Pop Culture from the Perspective of Cultural Soft Power [J]. Social Science Review, 2018(1): 123-127.

[10] He Shu, Du Rong. The Strategy and Balance of Cultural Output and Economic Input: outlook on the Development of China's Film Industry [J]. Film Review, 2018 (01): 67-69. 